\title{
Pengembangan Model Ulul Ilmi dalam Pembelajaran PAI untuk Pembentukan Karakter Mahasiswa Era Revolusi Industri 4.0
}

\author{
Aam Abdussalam ${ }^{1}$, Udin Supriadi ${ }^{2}$, \\ Muhamad Parhan $^{3 凶}$, \& Nurti Budiyanti ${ }^{4}$ \\ ${ }^{1234}$ Universitas Pendidikan Indonesia, Bandung \\ $凶$ parhan.muhamad@upi.edu
}

Riwayat naskah:

Diterima: 3 September 2020

Disetujui: 24 November 2020

Diterbitkan: 12 Desember 2020

\begin{abstract}
This paper aims to develop an Ulul Ilmi model in Islamic Education learning for the character of 21st-century students, which, of course, can help. Realize these national education goals - the research method used using a qualitative approach and literature study techniques in collecting data. Based on the findings, the Ulul Ilmi Model is very supportive in Islamic Religious Education learning because it has extreme divine values to achieve ma'rifatullah goals to shape 21st-century students' character. The method used is the method (1) the uswah hasanah method, an exemplary method that must be applied to an educator and passed on to students, (2) the ibrah mauidzah method, which is a learning method that must be delivered in the classroom, and (3) the targhib tarhib method, a method of strengthening for character building. Thus this pattern is later called the Ulul Ilmi model.
\end{abstract}

Keywords: character, model development, religious education, ulul ilmi

\begin{abstract}
Abstrak: Tulisan ini bertujuan untuk mengembangkan model Ulul Ilmi dalam pembelajaran PAI untuk pencapaian karakter mahasiswa abad 21, yang tentunya dapat membantu merealisasikan tujuan pendidikan Nasional. Metode penelitian yang digunakan dengan menggunakan pendekatan kualitatif dan teknik studi pustaka dalam pengumpulkan data. Berdasarkan hasil temuan, model Ulul Ilmi ini sangat memungkinkan untuk diterapkan dalam pembelajaran Pendidikan Agama Islam, karena memiliki nilai Ilahiyyah yang sangat kuat mencapai tujuan ma'rifatullah dalam rangka membentuk karakter mahasiswa abad 21. Metode yang digunakan ialah (1) metode uswah hasanah, yang merupakan metode keteladanan yang wajib diterapkan bagi seorang pendidik dan diwariskan kepada para peserta didik, (2) metode ibrah mauidzah, merupakan metode pembelajaran yang wajib untuk disampaikan di dalam kelas, dan (3) metode targhib tarhib, yakni metode penguatan untuk penanaman karakter. Dengan demikian pola inilah yang kemudian disebut sebagai model Ulul Ilmi.
\end{abstract}

Kata kunci: karakter, pendidikan keagamaan, pengembangan model, ulul ilmi 


\section{Pendahuluan}

Sukmadinata telah menggambarkan dua masalah besar yang terjadi dalam dunia pendidikan, khususnya di Indonesia, yaitu berkenaan dengan kuantitas dan kualitas pendidikan. Masalah pertama mengenai kuantitas pendidikan berupa penyediaan fasilitas belajar bagi semua anak didik di sekolah. Salah satu penyebab utama yang menuntut pengembangan kuantitas pendidikan adalah angka kelahiran. Masalah kedua yang dihadapi ialah masalah kualitas. Masyarakat dan para ahli pendidikan banyak yang mensinyalir bahwa mutu pendidikan dewasa ini belum seperti yang diharapkan. Banyak faktor yang mungkin melatarbelakangi hal tersebut, di antaranya ialah banyak pendidik yang tidak bekerja dengan sungguh-sungguh atau dikarenakan kemampuan profesionalisme pendidik yang kurang mumpuni. ${ }^{1}$

Salah satu akibat berkembangnya revolusi industri 4.0 abad 21 ini, pendidikan di Indonesia masih bersifat parsial, baik sistem, materi, maupun komponen yang ada dalam pendidikan itu sendiri. Salah satu komponen penting yang harus diperhatikan oleh seorang pendidik ialah pengembangan model pendidikan yang dilakukan di dalam kelas, termasuk di dalamnya yaitu pendidikan agama Islam. ${ }^{2}$ Melihat konteks pendidikan agama Islam, masih banyak pendidik yang tidak mampu mengembangkan serta menerapkan model pendidikan berbasis Qurani, sehingga merosotnya kualitas pendidikan di Indonesia ini tidak terlepas dari merosotnya kualitas yang dimiliki oleh para pendidik. Melihat kenyataan seperti ini, tentunya seorang pendidik dituntut untuk senantiasa meningkatkan kompetensinya dengan baik. $^{3}$ Undang-Undang Republik Indonesia nomor 14 Tahun 2005 tentang Pendidik Bab IV Pasal 10, menegaskan bahwa kompetensi pendidik meliputi kompetensi pedagogik, kompetensi kepribadian, kompetensi sosial, dan kompetensi profesional yang diperoleh melalui pendidikan profesi. ${ }^{4}$ Mengembangkan dan menerapkan model pendidikan merupakan tanggung jawab pendidik dalam rangka meningkatkan kompetensi pedagogiknya untuk dapat menunjang keberhasilan tujuan pendidikan sebagaimana termaktub dalam undang-undang Nomor 20 tahun 2003 tentang Sistem Pendidikan Nasional. ${ }^{5}$

Tujuan tersebut tidak akan tercapai jika kompetensi pedagogik tidak dikembangkan dan diaplikasikan dalam dunia pendidikan. Penulis menyajikan pengembangan model Ulul Ilmi sebagai salah satu solusi dari berbagai problematika yang terjadi untuk meningkatkan karakter mahasiswa abad 21. Ulul ilmi merupakan sebuah konsep yang dikembangkan dalam Al-Qur'an yang memiliki arti "orang yang berilmu". Karakteristik Ulul Ilmi ini memiliki andil yang cukup besar dalam menanamkan roh Islam ke dalam pengembangan model pendidikan, sebagai generasi yang siap dalam menghadapi tantangan zaman revolusi industri 4.0 Abad 21, untuk kembali menghadirkan nilai spiritual. Sebagaimana Sodiman mengatakan bahwa nilai-nilai spiritual ini akan hadir dengan adanya kesadaran Ilahiyyah, yang tentunya kesadaran ini perlu ditumbuhkan

\footnotetext{
${ }^{1}$ N S Sukmadinata, Pengembangan Kurikulum: Teori Dan Praktik (Bandung: PT Remaja Rosdakarya, 1997).

2 Salamah. "Peran Guru PAI dalam Pembentukan Karakter Siswa di Era Revolusi Industri 4.0." SCAFFOLDING: Jurnal Pendidikan Islam dan Multikulturalisme 2, no. $1 \quad$ (2020): 26-36. https://doi.org/10.37680/scaffolding.v2i1.281.

${ }^{3}$ Medina Nur Asyifah Purnama. "Analisis dan Pengembangan Desain Pembelajaran PAI Berbasis Karakter". QALAMUNA: Jurnal Pendidikan, Sosial, Dan Agama vol 11 no 1 (2019), 129-39. https://doi.org/10.5281/zenodo.3559232.

${ }^{4}$ Undang-Undang RI Nomor 14 tahun 2005 Tentang Guru dan Dosen. Cetakan 1, (Yogyakarta: Pustaka Yustisia, 2006).

${ }^{5}$ Bashori Muchsin, Moh Sulthon, and Abdul Wahid, Pendidikan Islam Humanistik: Alternatif Pendidikan Pembebasan Anak (Bandung: Refika Aditama, 2010).
} 
dalam pendidikan. Karena sejatinya pendidikan harus sejalan dengan tuntunan syariat Islam. ${ }^{6}$ Dengan tuntunan inilah manusia dapat mensinergikan ilmu dan iman menjadi amal shaleh, sehingga mampu menjadi pribadi yang unggul. ${ }^{7}$

Penelitian ini mengeksplorasi pengembangan model Ulul Ilmi berdasarkan kajian AlQur'an dalam pembelajaran PAI untuk pencapaian karakter mahasiswa abad 21. Pendekatan yang digunakan dalam penelitian ini dalam bentuk kualitatif dengan model analisis teks. Peneliti mengumpulkan data untuk dipilah dan dianalisis serta membuat sintesa data untuk kemudian memberikan catatan dan masukan terhadap pengembangan model Ulul Ilmi dalam pembelajaran PAI sebagai pencapaian karakter mahasiswa abad 21.

\section{Makna dan Karakteristik Ulul Ilmi}

Di dalam diskursus kajian Islam, orang yang memiliki pemahaman keagamaan yang mumpuni dikenal sebagai orang 'âlim atau 'ulamā. Kata 'àlim atau 'ulamā merupakan derivasi dari 'ilm yang dalam bahasa Indonesia diserap sebagai ilmu. Istilah ' $i l m$ merupakan term yang terdapat dalam Al-Qur'an dan disebutkan sebanyak 854 kali. Adapun kata ūlūl 'ilmi ini hanya diungkapkan satu kali saja yaitu dalam Qs. Alĩ Imrān ayat 18. Di mana ayat ini berkenaan dengan kesaksian para malāikat serta orang-orang yang berilmu bahwasanya tiada Tuhan yang berhak disembah melainkan Allah Yang Maha Adil. ${ }^{8}$

Berdasarkan hasil kajian penelitian, Ûlūl 'ilmi dimaknai sebagai seseorang yang mempunyai pemikiran yang analitis dan keteguhan hati dalam menjalankan aqidah sehingga dapat memadukan iman, ilmu, dan amal secara konsisten. Makna Ūlūl 'ilmi ini, mempunyai relasi makna dengan Ūlūl Albab dan Ulin Nuha yang terkandung dalam teks Al-Qur'an. Ketiga istilah ini mempunyai persamaan dalam hal penggunaan akal sebagai pembeda antara satu manusia dengan manusia yang lain. ${ }^{9} \bar{U} l \bar{u} l$ Albab adalah pemikir intelektual yang memiliki ketajaman analisis terhadap gejala dan proses alamiyah dengan metode ilmiah induktif dan deduktif, serta intelektual yang membangun kepribadian dengan żikir dalam keadaan dan sarana ilmiah untuk kemaslahatan dan kebahagiaan seluruh umat manusia. Sementara itu, Ulin nuha ialah individu yang mempunyai pemikiran yang jernih, sehingga dapat mencegah seseorang dari perbuatan yang tidak terpuji. ${ }^{10}$

Kata Ūlūl 'ilmi, Ulin nuha, dan Ūlūl albab yang terdapat dalam kitab suci Al-Qur'an mempunyai perbedaan meskipun sama-sama memiliki relasi makna pada optimalisasi pemikiran atau akal. Ūlūl albab, Ulin nuha dan Ūlūl 'ilmi secara substantif tidak hanya bermakna penggunaan akal semata tetapi juga berkaitan dengan hati (qalb). Akal atau pemikiran yang

\footnotetext{
${ }^{6}$ Musaddad Harahap and Lina Mayasari Siregar, "Konsep Pendidikan Islam Dalam Membentuk Manusia Paripurna," Jurnal Pendidikan Agama Islam Al-Thariqah 2, no. 2 (2017): $148-63$. https://doi.org/10.25299/althariqah.2017.vol2(2).1040

${ }^{7}$ Nurrahmah Nurrahmah, “Konsep Manusia Unggul: Kajian Atas Naskah Anis Al-Muttaqin,” Jurnal Lektur Keagamaan 11, no. 1 (2013): 181-202.

${ }^{8}$ Nurti Budiyanti, Ahmad Syamsu Rizal, and Elan Sumarna, "Implikasi Konsep Ūlūl 'Ilmi Dalam Al-Qurān Terhadap Teori Pendidikan Islam (Studi Analisis Terhadap Sepuluh Tafsīr Mu'Tabarah),” TARBAWY: Indonesian Journal of Islamic Education 3, no. 1 (2016): 51-74. https://doi.org/10.17509/t.v3i1.3459

${ }^{9}$ Budiyanti, Rizal, and Sumarna.

${ }^{10}$ Ulum, "Konsep Ulul Albab QS Ali-Imron Ayat 190-195 \& Relevansinya dengan Tujuan Pendidikan". Skripsi, Insitut Agama Islam Negeri Walisongo Semarang, 2011, 35-36. http://eprints.walisongo.ac.id/id/eprint/2226
} 
ditunjang dengan hati yang bersih akan membawa pada kebaikan sehingga antara akal dan hati tidak dapat dipisahkan satu sama lain dalam konteks ketiga istilah di atas. Adapun perbandingan ketiga term antara Ūlül albab, Ulin nuha dan Ülūl 'ilmi, dalam Al-Qur'an dapat digambarkan dalam bentuk tabel sebagaimana dalam Tabel 1 berikut:

Tabel 1. Ūlūl 'ilmi, Ūlūl albab, dan Ulin nuha

\begin{tabular}{|c|c|c|}
\hline Kata & Persamaan & Perbedaan \\
\hline $\bar{U} l \bar{u} l$ ‘ilmi & Mempergunakan akal & Menanamkan aqidah yang kuat \\
\hline $\bar{U} l \bar{l} l a l b a b$ & Mempergunakan akal & Menanamkan żikir dan fikir \\
\hline Ulin nuha & Mempergunakan akal & Penguatan akhlakul karimah \\
\hline
\end{tabular}

Jika merujuk pada deskripsi tabel 1, terdapat relasi makna yang sama antara konsep Ūlül 'ilmi, Úlūl albab, dan Ulin nuha yakni pada penggunaan akal. Begitu juga perbedaan di antara ketiga istilah tersebut saling berkaitan satu sama lain. Jika Ulul ilmi cenderung lebih menguatkan pada penanaman aqidah, Ulul albab berorientasi pada integrasi dzikir dan pikir, sedangkan Ulin nuha pada penguatan akhlak. Istilah Ūlūl 'ilmi, Ūlūl albab, dan Ulin nuha dalam Al-Qur'an merupakan cerminan dari perpaduan antara akal, zikir, dan akhlak yang menuntun seseorang pada kebaikan baik duniawi maupun ukhrawi. Predikat Ulul ilmi terhadap seseorang tidak didapatkan secara instan melainkan dengan ikhtiar yang maksimal dan berkelanjutan. Secara substantif, ilmu pengetahuan berasal dari Dzat yang Maha Mengetahui. Namun, ilmu pengetahuan bisa didapatkan dengan berbagai cara baik melalui perantara maupun hasil olah pemikiran. ${ }^{11}$

Dalam perspektif Islam terdapat dua cara untuk mendapatkan ilmu yakni dengan wahyu dan akal. Mufassir terkemuka Indonesia, Muhammad Quraish Shihab, mendeskripsikan jalan untuk mendapatkan ilmu pengetahuan yaitu dengan ilmu kasbi (pengetahuan didapatkan melalui ikhtiar lahiriah), dan 'ilmu laduni (ilmu yang didapatkan tanpa melalui ikhtiar apapun). Ilmu kasbi lazim ditempuh oleh para pencari ilmu dengan belajar pada guru, membaca buku, dan aktivitas ilmiah lainnya. Ilmu laduni hanya diberikan kepada orang-orang khusus atau yang terpilih. Ilmu kasbi dan ilmu laduni meskipun berbeda dari cara untuk memperolehnya namun keduanya secara esensial tetap berasal dari Allah Swt. Hal ini mengindikasikan bahwa Ülül ilmi merupakan Ilmu Kasbi sehingga setiap individu wajib berikhtiar dengan mengikuti semua proses dalam mencari ilmu yakni dengan mengoptimalkan akal, membersihkan hati, dan memaksimalkan indera yang lain untuk mendapat pengetahuan yang bertumpu pada kebenaran hakiki. ${ }^{12}$

Oleh karena itu, ikhtiar yang harus dilakukan untuk memeroleh ilmu pengetahuan bukan hanya mengandalkan kemampuan fisik saja tetapi juga dengan melibatkan hati sebagai penuntun pada jalan kebenaran. Dengan hati yang bersih dan ikhtiar yang maksimal, maka akan menuju pada jalan pengetahuan yang membawa kemaslahatan. Ikhtiar fisik dan hati yang dipadukan melalui tirakat atau berupaya menjauhkan diri dari segala yang dilarang agama dapat mengantarkan seseorang dalam mencari ilmu pada muara ketakwaan. Sebagaimana ayat-ayat dalam Al-Qur'an yang menyandingkan antara ilmu pengetahuan dan ketakwaan, Khaled M Abou

${ }^{11} \mathrm{~J}$ U Muliawan and A R Assegaf, Pendidikan Islam Integratif: Upaya Mengintegrasikan Kembali Dikotomi Ilmu Dan Pendidikan Islam (Yogyakarta: Pustaka Pelajar, 2005).

${ }^{12}$ M Q Shihab, Wawasan Al-Quran: Tafsir Tematik Atas Pelbagai Persoalan Umat (Bandung: Mizan, 1996). 
Fadl berpandangan bahwa jalan ketakwaan yang sesungguhnya adalah melalui pencarian ilmu pengetahuan bukan hanya ritual lahiriah semata. ${ }^{13}$

Ciri khas Ulul ilmi dalam Al-Qur'an di antaranya mempunyai kapasitas keilmuan yang bisa dipertanggungjawabkan, cakap dalam segala hal tentang peribadahan, mempunyai akhlak yang baik, keteguhan akidah, spiritualitas yang kuat dan dapat menebar kemaslahatan bagi lingkungan di sekitarnya. Tentu karakter Ulul ilmi dapat terlihat dari sikap yang konsisten dalam menjalankan perintah agama dan disempurnakan dengan ilmu pengetahuan yang diperolehnya sehingga tidak mengandalkan intelektualitas saja tetapi juga spiritualitas dan moralitas. Karakteristik Ūlūl 'ilmi ini dapat digambarkan dalam tabel 2 berikut:

Tabel 2. Klasifikasi Karakter Ūlūl ‘ilmi

\begin{tabular}{|c|c|c|c|c|c|}
\hline Kognitif & Afektif & Psikomotorik & Sosial & Etika & Spiritual \\
\hline Memiliki & Memiliki & Bersikap adil & Memberi & Budi bahasa & Memiliki aqidah yang kokoh \\
\hline ketajaman akal & $\begin{array}{l}\text { rasa kasih } \\
\text { sayang }\end{array}$ & & $\begin{array}{l}\text { dorongan } \\
\text { posotif }\end{array}$ & yang baik & \\
\hline $\begin{array}{l}\text { Memiliki ilmu } \\
\text { yang memadai }\end{array}$ & $\begin{array}{l}\text { Memiliki } \\
\text { semangat } \\
\text { yang tinggi }\end{array}$ & $\begin{array}{l}\text { Bersikap } \\
\text { bijaksana }\end{array}$ & $\begin{array}{l}\text { Memelihara } \\
\text { wasiat }\end{array}$ & $\begin{array}{l}\text { Sopan } \\
\text { santun }\end{array}$ & Memiliki iman yang kuat \\
\hline \multirow[t]{2}{*}{$\begin{array}{l}\text { Memiliki hujjah } \\
\text { dan bukti }\end{array}$} & & $\begin{array}{l}\text { Bersikap lapang } \\
\text { dada }\end{array}$ & $\begin{array}{l}\text { Memelihara } \\
\text { hubungan } \\
\text { harmonis }\end{array}$ & $\begin{array}{l}\text { Memiliki } \\
\text { tabiat yang } \\
\text { lurus }\end{array}$ & Memiliki hati yang suci \\
\hline & & & & & $\begin{array}{l}\text { Memiliki sikap khasyyah, } \\
\text { zuhud, tawadhu, wara', } \\
\text { syukur, ikhlas, dan taat }\end{array}$ \\
\hline
\end{tabular}

Dengan demikian berdasar klasifikasi karakter Ûlül 'ilmi pada tabel 2, terdapat perbedaan yaitu dimensi ketauhidan, spiritualitas, dan kekuatan batin. Ciri khas ini merangkum enam aspek yaitu spiritual, sosial, moral, psikomotorik, kognitif, dan afektif. Karakter inilah yang diperlukan mahasiswa abad 21 dalam mengahadapi berbagai persoalan dalam lingkungan pendidikan. Pendidikan Agama Islam sebagai pendidikan inti kehidupan memiliki peran penting dalam menumbuhkan karakter Ulul Ilmi tersebut.

\section{Pengembangan Model Ulul Ilmi dalam Pembelajaran PAI}

Pola pengembangan Ulul ilmi dalam pembelajaran pada hakikatnya merupakan salah satu pendekatan yang bisa dikembangkan oleh para guru untuk mencapai tujuan pembelajaran. Sementara itu, istilah pengembangan dimaknai oleh Hakam sebagai upaya untuk merekonstruksi atau menyempurnakan model hasil penelitian empiris yang dipadukan dengan hasil kajian teoretis dan pemikiran peneliti sehingga melahirkan alternatif model baru yang dapat menjadi rujukan para praktisi pendidikan. ${ }^{14}$ Dengan demikian, model Ulul Ilmi ini lahir sebagai pengembangan

${ }^{13}$ Khaled M Abou El Fadl, Atas Nama Tuhan: Dari Fikih Otoriter Ke Fikih Otoritatif, ed. R. Cecep Lukman Yasin. (Jakarta: Serambi Ilmu Semesta, 2004).

14 Kama Abdul Hakam. "Pengembangan Model Pembudayaan Nilai-Moral dalam Pendidikan Dasar di Indonesia: Studi Kasus di Sekolah Dasar Negeri Bandungrejosari 1 Kota Malang, Jawa Timur" in SOSIOHUMANIKA: Jurnal Pendidikan Sains Sosial dan Kemanusiaan, Vol.4, No.2 [November 2011], pp.159-184. Retrieved from https://mindamas-journals.com/sosiohumanika/article/view/445 
model pembelajaran PAI yang bertujuan untuk memperbaiki kondisi pembelajaran untuk mencapai tujuan yang diharapkan.

Model Ulul Ilmi merupakan model pembelajaran Qurani yang efektif menumbuhkan iman dan taqwa peserta didik dalam membentuk akhlakul karimah. Model ini dapat diterapkan dalam seluruh materi pembelajaran di kelas, akan tetapi keefektifan model tersebut sangat dipengaruhi oleh keterampilan yang dimiliki oleh sang pendidik. Mengingat ada delapan aspek keterampilan yang harus dikuasai sang pendidik, salah satunya ialah keterampilan dalam menyajikan materi pelajaran. Jika pendidik memiliki keterampilan dalam menyajikan materi pelajaran, maka model ini dapat membantu menyerap berbagai informasi dan mencapai tujuan dalam proses pembelajaran. Hal ini sepadan dengan pendapat Joyce dan Calhoun yang mengatakan bahwa pendidik yang sukses bukan sekedar penyaji yang karismatik dan persuasif, bukan pula mereka yang melibatkan para peserta didiknya dalam tugas-tugas yang bersifat kognitif dan sosial. ${ }^{15}$ Akan tetapi, pendidik yang sukses akan senantiasa mengajari peserta didik bagaimana menyerap dan menguasai informasi yang berasal dari penjelasannya kemudian diaplikasikan dalam kehidupan nyatanya. Penulis mendeskripsikan gambar pengembangan model Ulul Ilmi sebagai berikut:

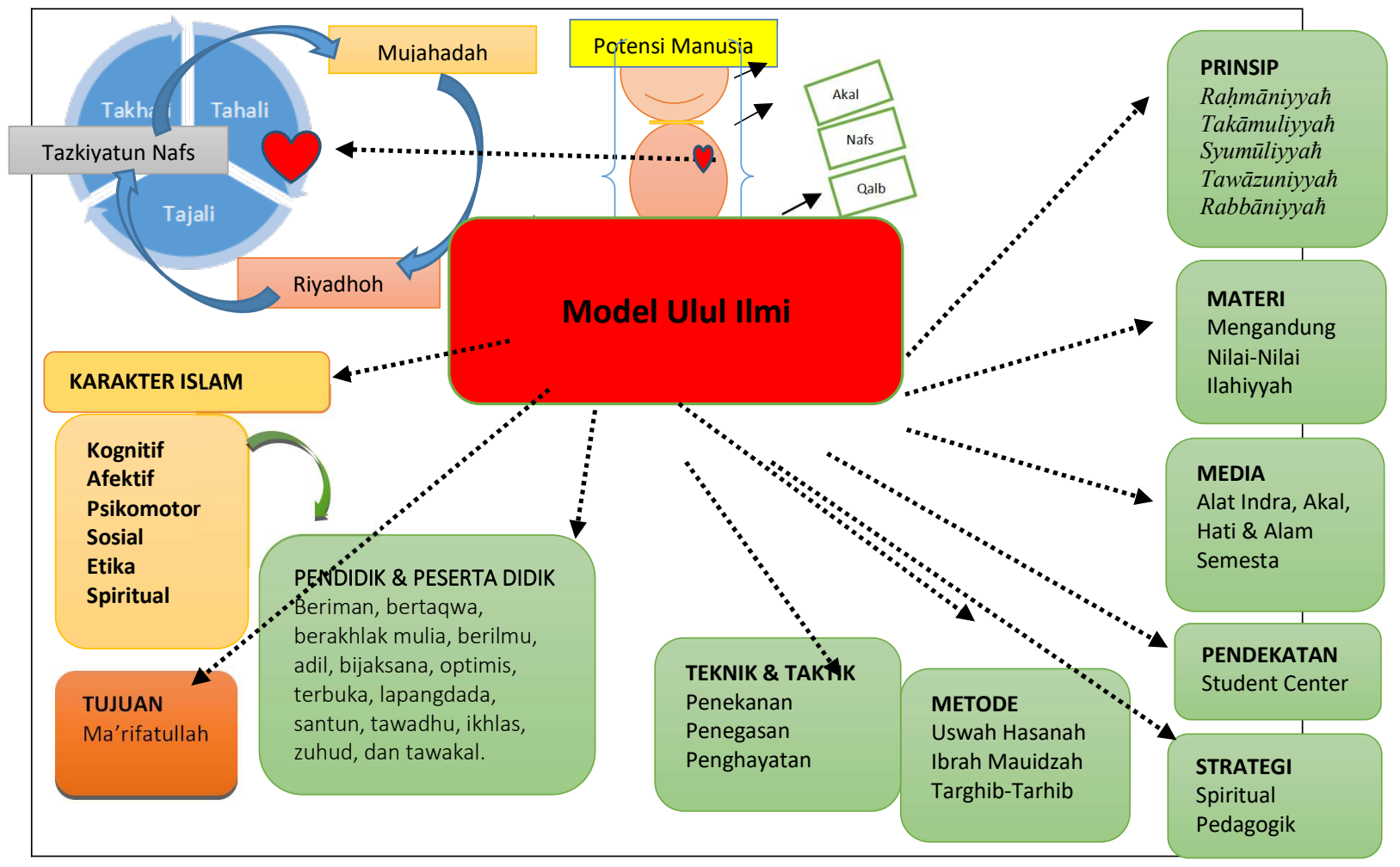

Gambar 1. Visualisasi Pengembangan model Ulul Ilmi

Model Ulul Ilmi ini sangat memungkinkan untuk diterapkan dalam pembelajaran Pendidikan Agama Islam, karena memiliki nilai Ilahiyyah yang sangat kuat. Sebagaimana pada Gambar 1 yang merupakan pengembangan model Ulul Ilmi untuk mencapai tujuan ma'rifatullah dalam rangka membentuk karakter mahasiswa abad 21. Jika Ulul Ilmi ini diformulasikan ke dalam sebuah model, maka perlu ada beberapa komponen di dalam kerangkanya. Menurut Joyce

${ }^{15}$ Joyce, B., Weil, M., \& Calhoun, E, Models of Teaching: Model-Model Pengajaran, edisi kedelapan. (terj. Achmad Fawaid dan Ateita Mirza). (Yogyakarta: Pustaka Pelajar, 2009), 8. 
dan Calhoun yang terangkum dalam buku Models of Teaching: kerangka yang harus ada dalam pengembangan model antara lain ialah (1) Rencana pembelajaran. (2) Skenario. (3) Tujuan pembelajaran. (4) Materi ajar. (5) Langkah-langkah pembelajaran. (6) Metode pembelajaran. (7) Sumber ajar. ${ }^{16}$

Metode targhib-tarhib yang terdapat dalam model Ulul Ilmi dapat diterapkan untuk menginternalisasikan ajaran Islam yang berhubungan dengan perintah-perintah dan laranganlarangan Allah. Bukan hanya dalam hal shalat, tapi juga materi lainnya seperti zakat, nikah, zina, pencurian, pelaku dzalim. dan lain sebagainya yang termasuk ke dalam bentuk perintah dan larangan Allah. Hal ini pasti akan berdampak positif bagi orang yang menegakkan perintah Allah dan menjauhi larangan-Nya dan sebaliknya hal ini dapat memberikan dampak negatif jika orang melalaikannya.

Analisis penulis, model pengajaran Ulul Ilmi ini akan memberikan dampak instruksional yang berkaitan dengan motivasi beragama, peningkatan keimanan serta pembentukan karakter. Adapun dampak penyerta ialah keterampilan survey dan proses ilmiah juga dapat menumbuhkan rasa ingin tahu mengapa Allah menetapkan demikian. Adapun Ma'rufin mengemukakan bahwa usaha pertama kali yang harus dilakukan seorang pendidik untuk memaksimalkan penerapan metode tersebut ialah dengan teknik lemat lembut dan menyentuh perasaan anak didik. Jika usaha tersebut belum cukup mempan, maka pendidik boleh menggunakan hukuman untuk membina kedisiplinan peserta didik. Dengan demikian perlu adanya kerjasama yang signifikan antara pendidikan keluarga dan pendidikan sekolah. ${ }^{17}$

\section{Kesimpulan}

Model Ulul Ilmi merupakan model pembelajaran Qurani yang efektif menumbuhkan iman dan takwa peserta didik dalam membentuk akhlakul karimah. Model Ulul Ilmi ini sangat memungkinkan untuk diterapkan dalam pembelajaran Pendidikan Agama Islam, karena memiliki nilai Ilahiyyah yang sangat kuat mencapai tujuan ma'rifatullah dalam rangka membentuk karakter mahasiswa abad 21. Pendekatan yang digunakan dalam model ini adalah student center. Strategi yang digunakan adalah pendekatan spiritual pedagogik dengan kombinasi metode yang disesuaikan dengan materi. Metode yang digunakan ialah (1) metode uswah hasanah: yang merupakan metode yang wajib diterapkan bagi seorang pendidik, dan tentunya seorang pendidik harus memiliki sikap religius untuk diwariskan kepada para peserta didik, (2) metode ibrah mauidzah: merupakan metode yang wajib untuk disampaikan di dalam kelas, dan (3) metode targhib tarhib: merupakan metode penguatan untuk penanaman karakter. Adapun teknik yang digunakan menggunakan teknik penanaman kelembutan dan ketegasan yang disesuaikan dengan situasi dan kondisi dalam penyampaian materi pembelajaran. Kemudian taktik yang digunakan berkaitan dengan penampilan pendidik di dalam kelas baik secara verbal maupun non verbal. Pada akhirnya, pola inilah yang kemudian disebut sebagai sebuah model Ulul Ilmi.

\footnotetext{
${ }^{16}$ Joyce \& Calhoun

${ }^{17}$ Ma'rufin, Metode Targhib dan Tarhib (Reward and Punishment dalam Pendidikan Islam), Risalah,Vol.1 No.1, 2015,70. https://doi.org/10.31943/jurnal_risalah.v2i1.13
} 


\section{Referensi}

Budiyanti, Nurti, Ahmad Syamsu Rizal, and Elan Sumarna. "Implikasi Konsep Ūlūl 'Ilmi Dalam Al-Qurān Terhadap Teori Pendidikan Islam (Studi Analisis Terhadap Sepuluh Tafsīr Mu'Tabarah)." TARBAWY: Indonesian Journal of Islamic Education 3, no. 1 (2016): 51-74. https://doi.org/10.17509/t.v3i1.3459

Fadl, Khaled M Abou El. Atas Nama Tuhan: Dari Fikih Otoriter Ke Fikih Otoritatif. Edited by R. Cecep Lukman Yasin. Jakarta: Serambi Ilmu Semesta, 2004.

Hakam, Kama Abdul. "Pengembangan Model Pembudayaan Nilai-Moral dalam Pendidikan Dasar di Indonesia: Studi Kasus di Sekolah Dasar Negeri Bandungrejosari 1 Kota Malang, Jawa Timur" in SOSIOHUMANIKA: Jurnal Pendidikan Sains Sosial dan Kemanusiaan, Vol.4, No.2 [November 2011], pp.159-184. Retrieved from https://mindamasjournals.com/sosiohumanika/article/view/445

Harahap, Musaddad, and Lina Mayasari Siregar. "Konsep Pendidikan Islam Dalam Membentuk Manusia Paripurna.” Jurnal Pendidikan Agama Islam Al-Thariqah 2, no. 2 (2017): 148-63. https://doi.org/10.25299/althariqah.2017.vol2(2).1040

Joyce, B., Weil, M., \& Calhoun, E. Models of Teaching: Model-Model Pengajaran, edisi kedelapan. (terjemah Achmad Fawaid dan Ateita Mirza). Yogyakarta: Pustaka Pelajar, 2009.

Ma'rufin. Metode Targhib dan Tarhib (Reward and Punishment dalam Pendidikan Islam), Risalah,Vol.1 No.1, 2015:70. https://doi.org/10.31943/jurnal_risalah.v2i1.13

Muchsin, Bashori, Moh Sulthon, and Abdul Wahid. Pendidikan Islam Humanistik: Alternatif Pendidikan Pembebasan Anak. Bandung: Refika Aditama, 2010.

Muliawan, J U, and A R Assegaf. Pendidikan Islam Integratif: Upaya Mengintegrasikan Kembali Dikotomi Ilmu Dan Pendidikan Islam. Yogyakarta: Pustaka Pelajar, 2005.

Nurrahmah, Nurrahmah. "Konsep Manusia Unggul: Kajian Atas Naskah Anis Al-Muttaqin." Jurnal Lektur Keagamaan 11, no. 1 (2013): 181-202.

Purnama, Medina. "Analisis Dan Pengembangan Desain Pembelajaran PAI Berbasis Karakter". QALAMUNA: Jurnal Pendidikan, Sosial, Dan Agama vol 11 no 1 (2019), 129-39. https://doi.org/10.5281/zenodo.3559232.

Salamah, Salamah. "Peran Guru PAI dalam Pembentukan Karakter Siswa di Era Revolusi Industri 4.0." SCAFFOLDING: Jurnal Pendidikan Islam dan Multikulturalisme 2, no. 1 (2020): 26-36. https://doi.org/10.37680/scaffolding.v2i1.281.

Shihab, M Q. Wawasan Al-Quran: Tafsir Tematik Atas Pelbagai Persoalan Umat. Mizan, 1996.

Sukmadinata, N S. Pengembangan Kurikulum: Teori Dan Praktik. Bandung: PT Remaja Rosdakarya, 1997.

Ulum, "Konsep Ulul Albab QS Ali-Imron Ayat 190-195 \& Relevansinya dengan Tujuan Pendidikan". Skripsi, Insitut Agama Islam Negeri Walisongo Semarang, 2011, 35-36. http://eprints.walisongo.ac.id/id/eprint/2226

Undang-Undang RI Nomor 14 tahun 2005 Tentang Guru dan Dosen. Cetakan 1, Yogyakarta: Pustaka Yustisia, 2006. 